УДК $74: 005: 003:=' . .06:=161.2+76+7.05 / 04 / 06 / 08$

DOI https://doi.org/10.24919/2308-4863/34-1-8

\author{
Руслан ГАЛИШИЧ, \\ orcid.org/0000-0002-2459-7580 \\ кандидат мистецтвознавства, \\ доиент кафедри дизайну та основ архітектури \\ Інституту архітектури та дизайну \\ Начіонального університету «Львівська політехніка» \\ (Львів, Україна) Ruslan.Y.Halyshych@lpnu.иa
}

Віталіна КРОХМАЛЬ, orcid.org/0000-0001-7790-6773 студентка II курсу магістратури

Інституту архітектури та дизайну Начіонального університету «Львівська політехніка» (Львів, Украӥна) Vitalina.Krokhmal.MnDZZV.2019@lpnи.иа

\author{
Ольга МЕР' \\ orcid.org/0000-0002-4178-2286 \\ кандидат архітектури, \\ доиент кафедри дизайну та основ архітектури \\ Інституту архітектури та дизайну \\ Наџіонального університету «Львівська політехніка» \\ (Львів, Україна) Olha.V.Merie@lpпи.иа
}

\title{
АКТУАЛЬНІСТЬ ЗАСТОСУВАННЯ КАЛІГРАФІЧНОГО УКРАЇНСЬКОГО ПИСЬМА В СУЧАСНОМУ ГРАФІЧНОМУ ДИЗАЙНІ
}

Уперше введено в науковий обіг фактологічні й аналітичні матеріали про застосування каліграфічного українського письма в сучасному графічному дизайні. Визначено актуальність застосування каліграфічного українського письма в різних видах сучасного графічного дизайну методами: емпіричних досліджень (застосовано анкетування мешканиів Украӥни на основі авторської анкети, методику аналізу на основі моделі AIDA й гештальт-психологіï); камеральних досліджень (містили комплексне дослідження бібліографії за тематикою дослідження з ї̈ аналізом і систематизацією щзодо формотворення літер у дизайні); застосування системного підходу, щзо полягав у комплексному дослідженні як єдиного ијілого типографіки, шрифтових каліграфічних композицій, способів $i$ засобів формотворення шрифту, його характеристики й застосування в графічному дизайні поліграфічної продукиії; порівняльного аналізу. Виявлено основні засоби й способи художнього формотворення каліграфічного украӥнського письма. Досліджено, що різна поліграфічна продукиія (плакати, етикетки, обгортки, палітурки книг) мають свої характерні особливості в сучасному графічному дизайні з використанням каліграфічного українського письма; унікальність і креативність сучасних шрифтових каліграфічних композицій притягує увагу людини, викликає в неї інтерес, бажання та закликає до дій; формотворення літер каліграфічного письма в дизайні етикеток згідно з характеристикою задає унікальність композиції, створює композиційний зв'язок; сучасне каліграфічне оформлення обкладинок книжок акиентує на собі увагу внаслідок використання яскравих, контрастних форм; у дизайні обгорток та пакування каліграфічний шрифт вишуканий, емоційний i настроєвий; у текстовому оформленні дизайну плакату сучасний каліграфічний шрифт динамічний, таким чином, він викликає в людини інтерес до змісту повідомлення. Згідно з результатами емпіричних досліджень встановлено, щь естетика каліграфічного шрифту гарніша, ніж звичайні гротескові чи антиквенні шрифтові гарнітури; найчастіше каліграфічне письмо зустрічається в дизайні етикеток, плакатів, сертифікатів, запрошень; згідно з візуальним сприйманням, більшість респондентів обрали дизайн із використанням каліграфічного письма. Встановлено, щз в різних дизайнерських вирішеннях каліграфія працює по-різному, позаяк, залежсть від індивідуальних особливостей сприймання людиною текстового повідомлення, формотворчих особливостей літер, аспекту читабельності й емоиійного забарвлення писаної шрифтової гарнітури.

Ключові слова: каліграфічне украйнське письмо, типографіка, графічний дизайн, шрифт, поліграфічна продукиія, формотворення літер. 


\title{
Ruslan HALYSHYCH, orcid.org/0000-0002-2459-7580 \\ Candidate of Art History, Associate Professor at the Department of Design and Architecture Fundamentals Institute of Architecture and Design of the Lviv Polytechnic National University (Lviv, Ukraine) Ruslan.Y.Halyshych@lpnu.ua
}

Vitalina KROKHMAL, orcid.org/0000-0001-7790-6773

Second-year Master's Student Institute of Architecture and Design of the Lviv Polytechnic National University (Lviv, Ukraine) Vitalina.Krokhmal.MnDZZV.2019@lpnu.ua

\author{
Olha MERIE, \\ orcid.org/0000-0002-4178-2286 \\ Candidate of Art History, \\ Associate Professor at the Department of Design and Architecture Fundamentals \\ Institute of Architecture and Design \\ of the Lviv Polytechnic National University \\ (Lviv,Ukraine) Olha.V.Merie@lpnu.ua
}

\section{RELEVANCE OF APPLICATION CALLIGRAPHIC UKRAINIAN WRITING IN MODERN GRAPHIC DESIGN}

For the first time introduced into the scientific circulation factual and analytical materials on the use of calligraphic Ukrainian writing in modern graphic design. The relevance of the use of calligraphic Ukrainian writing in different types of modern graphic design by methods: empirical research (questionnaires of Ukrainian residents based on the author's questionnaire, analysis methodology based on AIDA model and gestalt psychology were applied); camera studies (included a comprehensive study of bibliography on the subject of the study with its analysis and systematization on the formation of letters in the design; the use of a systematic approach, which consisted in a comprehensive study as a single whole typography, font calligraphic compositions, methods and means of font forming, its characteristics and application in graphic design of printing products; method of comparative analysis). The main means and methods of artistic forming of calligraphic Ukrainian writing have been identified. It is investigated that: different printing products (posters, labels, wrappers, bindings of books) have their own characteristics in modern graphic design using calligraphic Ukrainian writing; uniqueness and creativity of modern font calligraphic compositions attracts human attention, causes interest, desire, and calls for action; forming the letters of calligraphic writing in the design of labels according to the characteristic sets the uniqueness of the composition, creates a compositional relationship; modern calligraphic design of book covers focuses on itself due to the use of bright, contrasting forms; in the design of wrappers and packages, the calligraphic font is refined, emotional and moody; in the text design of the poster design, the modern calligraphic font is dynamic, thus attracting a person's interest in the content of the message. According to the results of empirical studies it is found that the aesthetics of calligraphic font are more beautiful than conventional grotesque or antique font headsets; most often calligraphic writing is found in the design of labels, posters, certificates, invitations; according to visual perception, the majority of respondents chose the design using calligraphic writing. It was established that in different design solutions calligraphy works differently, because it depends on: individual characteristics of the person's perception of text message, form-making features of letters, aspect of readability and emotional color of the written font headset.

Key words: calligraphic Ukrainian writing, typography, graphic design, font, printing products, letter forming.

Постановка проблеми. Незважаючи на стрімкий розвиток графічного дизайну в Україні й зростання ринкових вимог до емоційного дизайну, досі українськими науковцями не здійснено грунтовних наукових досліджень щодо каліграфічного українського письма в сучасному дизайні, в тому числі поліграфічної продукції. Значна частка писаних шрифтів у поліграфічній продукції викликає потребу в дослідженні їх місця та ролі в становленні формування та подальшого розвитку графічного дизайну в Україні.

Аналіз досліджень. Найгрунтовніше каліграфічне українське письмо, його стан і розвиток дослідив український художник-графік В. Чебаник (Чебаник, 2007). Більшість каліографів досліджували окремі питання каліграфічного письма, графічні прийоми, візуальну мову типографіки, взаємовпливи шрифтів, використання різних гар- 
нітур у графічному дизайні тощо: Тоотс Віллу (Тоотс Виллу, 1966), М. Різник (Різник, 1978), А. Капр (Капр, 1979), Л. Проненко (Проненко, 1990), Г. Кнабе (Кнабе, 2006), В. Мітченко (Мітченко, 1992; Мітченко, 2007; Мітченко, 2018), О. Лаврентьєва (Лаврентьева, 2008), І. Дудник (Дудник, 2009); зокрема, розвиток каліграфічного мистецтва досліджував Г. Задніпряний (Задніпряний, 2018); прийоми побудови композиційних вирішень із використанням шрифтових гарнітур у комплексному цілісному оформленні досліджували О. Калашнікова (Калашнікова, 2011) та А. Макарова (Макарова, 2014); М. Ісмайлова дослідила історію та шлях розвитку типографіки періоду, в який сформувалися основоположні принципи дизайну поліграфічної продукції, що вплинули на подальший розвиток типографіки (Ісмайлова, 2015: 61-70; Ісмайлова, 2016: 24-32; Ісмайлова, 2019) тощо (Сучасний український шрифтовий дизайн; Той, що «грає буквами», 2007: 21). Сучасні дослідники описують каліграфію та виділяють основні засоби й способи створення писаних композицій: Г. Задніпряний (Задніпряний, 2018: 13-18), О. Умпелева (Умпелева, 2019), А. Чекаль (Чекаль, Красота каллиграфии). Значно менше уваги дослідниками було приділено засобам і способам художнього формотворення шрифту, використанню писаних гарнітур у сучасному графічному дизайні та їх місцю в дизайні, в тому числі в поліграфічній продукції.

Мета статті-введення в науковий обіг фактологічних та аналітичних матеріалів про застосування каліграфічного українського письма в сучасному графічному дизайні. Завдання розвідки - дослідити основні засоби, способи й принципи художнього формотворення каліграфічного українського письма в типографіці сучасного графічного дизайну (в оформленні плакатів, етикеток, обгорток, палітурок книг тощо); визначити актуальність застосування каліграфічного українського письма в різних видах сучасного графічного дизайну різними методами наукових досліджень; обгрунтувати основні тенденції, які застосовуються сучасними українськими дизайнерами у створенні композиційних вирішень типографіки з використанням каліграфічного українського письма; дослідити, яким чином писані шрифтові композиції використовуються та взаємодіють в сучасному графічному дизайні.

Виклад основного матеріалу. Відомий український художник-графік Василь Чебаник присвятив останні десятиріччя своєї діяльності дослідженню української каліграфічної писемності й виклав результати досліджень та ідеї в праці «Графіка української мови» (Проєкт «Графіка україн- ської мови»), в якій запропоновано створення державного каліграфічного шрифту «Рутенія», який базується на історичних українських почерках та міг би виконувати роль національного державного атрибута й засобу самоідентифікації української нації. Про створення ним вдалого візуального образу українського шрифту зазначали О. Загаєцька (Загаєцька, 2006: 172-176), Ю. Полтавська в праці «Серцем відданий книзі» (Полтавська, 2011: 16-24). Г. Задніпряний, досліджуючи стан розвитку каліграфічного мистецтва, писав: «Каліграфія - прекрасна гілка на дереві шрифтів» (Задніпряний, 2018: 13-18). Нині в українському графічному дизайні можна простежити багато різних стилів, дизайнери дедалі частіше вдаються до різних прийомів створення цікавої гармонійної композиції. Дедалі частіше можна побачити використання різних шрифтових гарнітур у формотворенні образу. Графічний дизайн, в якому використаний каліграфічний шрифт, створює емоційний, настроєвий, вишуканий образ (Рудер, 1982). Більшість людей нині сприймають каліграфію виключно як один із видів образотворчого мистецтва. Хтось вважає його неактуальним, а хтось - модною тенденцією сьогодення, популярним напрямом у сучасній культурі, особливо в графічному дизайні поліграфічної продукції. Майстерний малюнок каліографа завжди заворожує єдністю композиції та вільного творчого пориву, вираженого в ритмі, мелодії літер та їх переплетенні. Експресія та стриманість - це дві сторони каліграфічного мистецтва, воно може надати рекламі як грайливості, так і строгості. «Проблеми тексту та його графічного контексту, як правило, розглядаються 3 боку шрифтового дизайну та історії шрифтів, типографіки, каліграфії < ..>» (Лаврентьева, 2008: 8-9).

Каліграфічне письмо у сучасному дизайні України все більше набуває цифрового вигляду, ручна графіка шрифту залишилася лише в різних видах дизайну запрошень і листівок. Це мистецтво відіграє важливу роль у творенні композиційних вирішень і гармонійних поєднань із графічними елементами. Роль каліграфії в графічному дизайні українських майстрів важко переоцінити, адже натепер роботи, в яких використано шрифт, зустрічаються майже в кожного дизайнера, композиційні вирішення з використанням писаних літер можна побачити в більшості друкованої поліграфічної продукції.

Сучасна каліграфія досить різноманітна - від побутових рукописних написів на листівках до високого мистецтва, в якому експресія написаного рукою знака не завжди народжує чіткі літерні 
форми. Класична каліграфія значно відрізняється від різних шрифтових гарнітур. У кожного дизайнера $є$ своя особлива манера каліграфічного письма, який він використовує у створені цікавого графічного дизайну. В Україні $є$ багато талановитих каліографів, котрі мають свою унікальну стилістику подачі й поєднання каліграфічних композицій, свій унікальний почерк, манеру, яка робить дизайн впізнаваним і цікавим. За допомогою письма вони передають настрій, емоції, образи. Основне завдання дизайнерів-каліографів полягає в тому, щоб, крім стилістики, передати читабельність текстового повідомлення. Суть каліграфічної писемності завжди полягала у вишуканому, стильному зображенні композиції, iї органічному й самобутньому образі (Умпелева, 2019: 25).

Нове покоління графічних дизайнерів-каліографів починає зростати, все більше людей прагне збагачувати графічну мову своєю особливою каліграфічною стилістикою - для того, щоб за допомогою почерку ідентифікувати свою особистість, виокремитися серед інших. Нині в українських дизайнерів повертається інтерес до леттерінгу окремих літер і шрифтових каліграфічних написів. Мода на такий спосіб виконання шрифтових композицій дещо згасла на початку 1990-их через масове захоплення комп'ютерними засобами під час роботи з текстами, проте наразі багато дизайнерів та ілюстраторів у всьому світі захоплюються каліграфією.

Серед українських представників цього напряму можна згадати, як приклад, київських майстринь сестер Вікторію та Віталіну Лопухіних, котрі використовують каліграфію для шрифтових композицій книг і тематичних плакатів. Вміння не лише професійно малювати, а й використовувати поєднання шрифтових композицій у різних галузях графічного проєктування для етикеток і пакувань різної продукції демонструє івано-франківський дизайнер Ярослав Шкрібляк. Яскравим представником сучасності в шрифтовому дизайні можна назвати луцького каліографа Кирила Ткачова. За вісімнадцять років роботи дизайнером-графіком йому доводилось працювати над фірмовими стилями, ілюстраціями й оформленням книжок, зокрема, він розробив шрифт для бренду міста Луцьк, різні шрифтові каліграфічні плакати, шрифти для відомих брендів, які $є$ актуальними й впізнаваними.

Отже, застосування каліграфічного письма в дизайні поліграфічної продукції набуло популярності за останні роки й продовжує активно розвиватися в наш час. Дизайнери вміло компонують шрифтові авторські композиції з акциндентними гарнітурами, створюючи цікавий і стиль- ний дизайн. Засобами створення каліграфічних композицій у поліграфічній продукції виступають пропорція, контраст, статика або динаміка літер, симетричність. Способами художнього формотворення $\epsilon$ форма й контрформа, складний ритм, врівноваженість, варіабельність текстового оформлення (Рудер, 1982). Аналіз цілісного образу здійснюється на основі елементів, які поєднуються між собою (гештальт-психологія), та за допомогою рекламної моделі AIDA (акронім від англ. Attention, Interest, Desire, Action / увага, інтерес, бажання, дія). Використання цих засобів і способів можна простежити в каліграфічних композиціях, які використовуються в сучасному дизайні поліграфічної продукції. Наприклад, у дизайні етикеток для сиру “Bellini” використаний контрастний, динамічний, асиметричний каліграфічний шрифт, в якому простежується декоративність літер. Класичний настрій гарнітури творить естетику врівноваженості шрифту. За моделлю AIDA шрифтову композицію можна схарактеризувати таким чином: формотворення шрифту, його унікальність і креативність притягує увагу людини й викликає інтерес до самого дизайну етикетки, пробуджує бажання спробувати продукт. У порівнянні $з$ лаконічними типографічними композиціями форма й контрформа в каліграфії декоративна, іронічна, сприймається як одне ціле. Пропорції літер у каліграфії можуть бути різними, що створює контраст форми, але водночас продукує комплексну гармонійну композицію. У дизайні обкладинок книг можна простежити використання динаміки й контрасту каліграфічного шрифту, складний ритм і варіабельність текстового оформлення. Текстове оформлення акцентує на собі увагу, вражає та захоплює, в порівнянні з гротескним шрифтом каліграфічна гарнітура зацікавлює споживача $з$ першого погляду, контраст форми шрифту пробуджує грайливий настрій. Натепер можна простежити використання каліграфічного шрифту в дизайні пакування та обгорток для цукерок, наприклад, у дизайні цукерок «Шедевр». Каліграфічний шрифт, створений для цієї фірми, вишуканий, статичний і симетричний. Негативний простір форми шрифту врівноважений, простий і стриманий. Плавні лінії шрифту вказують на вишуканість та якість самої продукції. Споживача зацікавлює гарнітура каліграфічного українського шрифту, яка привертає увагу, викликає до себе інтерес і бажання придбати товар.

Каліграфічний шрифт із легкістю поєднується та взаємодіє в композиції з простими шрифтовими гарнітурами. У порівнянні з гротескним шрифтом, який використано в дизайні, він вишуканий, 
емоційний і настроєвим. Особливий емоційний настрій створює каліграфічна шрифтова гарнітура в плакатах. Відповідно до змісту повідомлення, яке несе плакат, каліографи створюють особливий шрифт. У різних прикладах застосування шрифтової композиції для плаката простежується динаміка форми. Літери пропорційні, але своїм характером створюють тематичний настрій. Форма літер легка, врівноважена, співвідноситься 3 композицією та відповідає характеру текстового змісту. Акцент каліграфічного шрифту затримує на собі увагу людини, викликає інтерес до змісту, бажання задуматися над сенсом тексту й закликає до дії.

Отже, основні способи й засоби, які простежуються у формотворенні каліграфічного українського шрифту, притаманні для композиційних вирішень дизайну сучасної поліграфічної продукції, їх можна побачити в дизайні етикеток, обгорток, пакування, обкладинок книг, журналів, плакатів тощо. Основними принципами гармонійної композиції сучасних каліграфічних шрифтових гарнітур є: співрозмірність літер щодо композиції, цілісність та єдність, субпідрядність (підпорядкованість), повторення цілого в частині, візуальний і тематичний шрифтовий зв'язок, гармонійне співвідношення до композиційного центру, емоційний характер форми шрифту. У дизайні деяких етикеток яскраво виражена співрозмірність літер відповідно до композиції, поєднання схожих шрифтових гарнітур у комплексі створює цілісність. Формотворення літер продукує тематичний шрифтовий зв'язок, гармонічний дизайн етикетки задає емоційний характер форми. В органічній шрифтовій гарнітурі обкладинок книги можна простежити гармонію в співвідношенні щодо центру композиції, шрифт пов'язаний між собою повторювальними формами. Загалом, літери становлять цілісну й завершену композицію. Принципи художнього формотворення гармонійних шрифтових каліграфічних композицій простежуються в оформленні тематичних плакатів. Співрозмірність літер пропорційна щодо композиції, єдність форми створює повторювальні елементи каліграфічних літер, які доповнюють одна одну.

Сучасне каліграфічне письмо має свої композиційні вирішення, які вирізняють його 3-поміж інших шрифтових гарнітур. У порівнянні зі звичайною антиквою або гротеском, каліграфічний український шрифт емоційний, настроєвий, легкий у композиційному вирішенні. Сучасний стан речей у галузі каліграфічного шрифту напряму залежить від розвитку технологій та інструментів. Спосіб електронного виводу зображення літери на монітор дозволяє дизайнеру створювати різні види поліграфічної продукції та реалізувати їх. Тепер не потрібно писати пером кожний постер або обгортку книги, тим самим каліграфічним шрифтом можна зробити рисунок на папері, оцифрувати його й перевести в електронне зображення. Вникнувши в сутність процесу відтворення шрифту рукою та за допомогою електронних пристроїв, можна помітити такий важливий аспект, як міра залученості або співучасть того, хто надає візуальної форми тексту. Різні види шрифту, які створює каліограф, розподіляються за принципом техніки відтворення та мають різний ступінь попиту в суспільстві (Мітченко, 2018: 36). На перший погляд, інші види шрифту, такі як мальовані чи писані, втрачають своє значення, ставши об'єктом інтерпретації майстрів каліграфії, але в сучасному дизайні можна спостерігати тенденції розвитку каліграфічного письма. 3 різноманітності використання каліграфічних українських шрифтів можна визначити основні тенденції письма в дизайні: використання динамічних шрифтових гарнітур у композиціях, гармонійне компонування контрастних шрифтів між собою, що створює емоційний, вишуканий характер форми, складну ритмічність і варіабельність текстового оформлення.

Результати анкетування. Для визначення стану розвитку й місця каліграфічного українського письма в графічному дизайні Віталіною Крохмаль під керівництвом Ольги Мер'є було укладено анкету й проведено анкетування серед мешканців України 3 подальшою систематизацією даних (рис. 1). Зокрема, в дослідженні взяли участь 40 осіб із різних міст України у віці від 18 до 35 років (у тому числі професійні графічні дизайнери). Серед респондентів більшість були чоловіки (57,1 \%), жінки становили $42,9 \%$, вікова категорія більшості опитаних становила 22 роки $(62,5 \%), 23$ роки (15\%), 24 роки (10\%), вік решти респондентів коливався від 26 до 35 років. Згідно 3 опитуванням, усім респондентам каліграфічне письмо подобається (100\%), більшість вважає, що каліграфічне письмо гарніше в оформленні різної поліграфічної продукції (57,1 \%), також друковану рекламу 3 використанням каліграфічного шрифту зустрічають $57,1 \%$ опитаних. Найчастіше застосування каліграфічного письма респонденти можуть побачити в дизайні етикеток (42,9 \%), дизайні плакатів (42,9\%) та дизайні сертифікатів, запрошень (14,3 \%). На думку респондентів, найхарактернішою шрифтовою гарнітурою для українського графічного дизайну $\epsilon$ антиква $(42,9 \%)$, гротескному шрифту надали перевагу (26,6 \%), така ж кількість респондентів 
Галишич Р., Крохмаль В., Мер’є О. Актуальність застосування ...

1) $\mathrm{Biк}$

40 відповідей

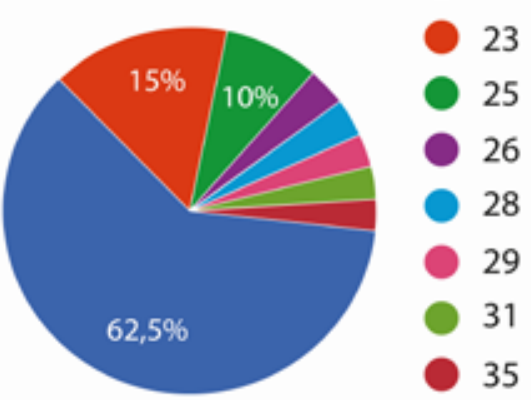

3) Чи подобається Вам каліграфічне письмо?

40 відповідей

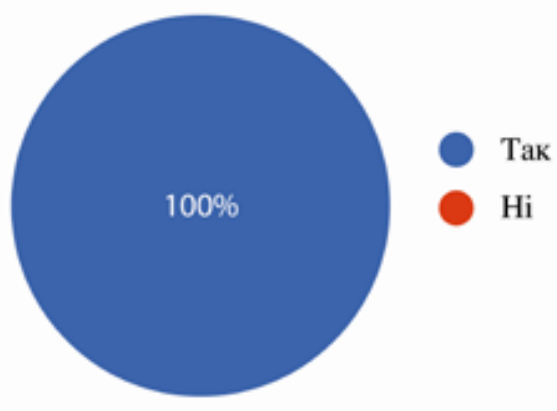

5) Як часто Ви зустрічаєте друковану рекламу, в якій використовуеться каліграфічне письмо?

40 ві,зповідей

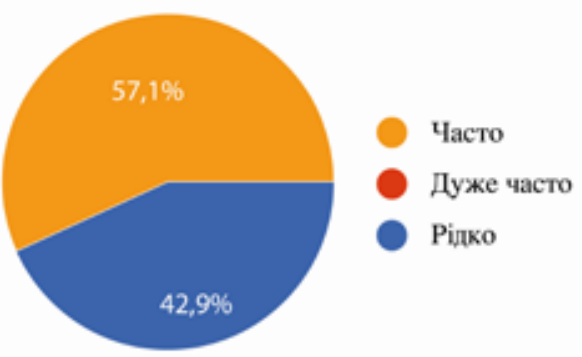

7) Які шрифтові гарнітури, на Вашу думку, характерні для українського графічного дизайну на сьогоднішній день?

40 відповідей

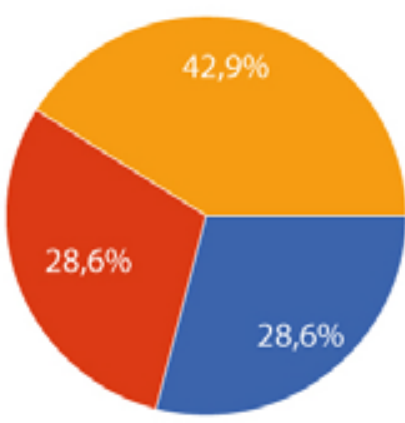

Каліграффічний

Гротеск

Антиква

\section{2) Стать}

40 відповідей

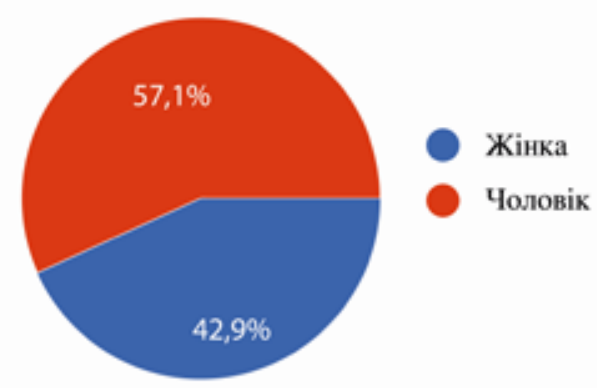

4) Чи вважасте Ви, що каліграфічне письмо у дизайні поліграфічної продукції (упаковок, плакатів, обкладинок, обгорток) $\varepsilon$ гарнішим, ніж інший гротесковий шрифт?

40 вімповіле

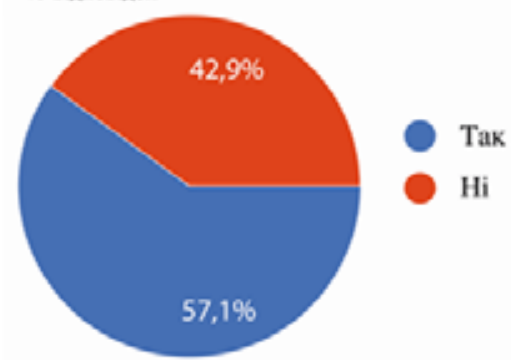

6) Де найчастіше Ви бачите застосування каліграфічного письма?

40 відповізей

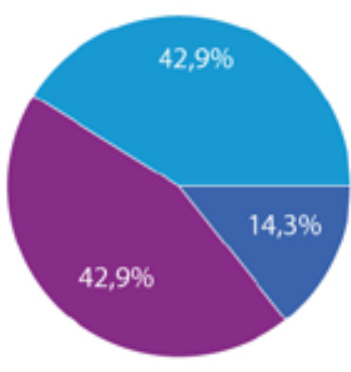

- Етикетки

У паконки

Летучки

Обклапинки журналів/книг

Плакати

Сертифікати /3апропения

8) Який саме варіант дизайну поліграфічної продукції Вам подобається найбільше? 40 відповідей

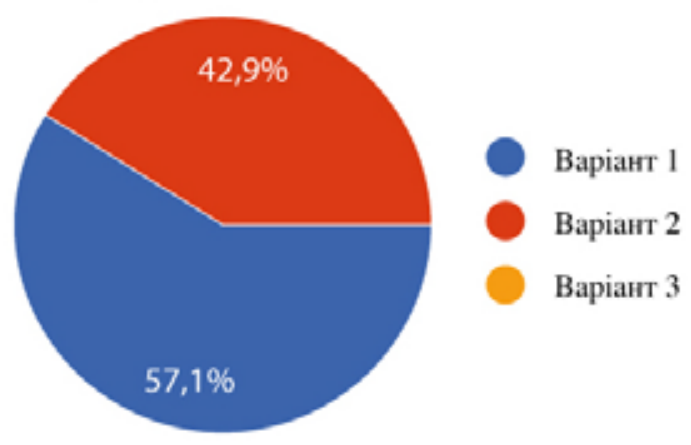

Рис. 1. Діаграми, що відбивають результати емпіричних досліджень (анкетування) 
9) Яких відомих українських каліграфістів Ви знаєте?

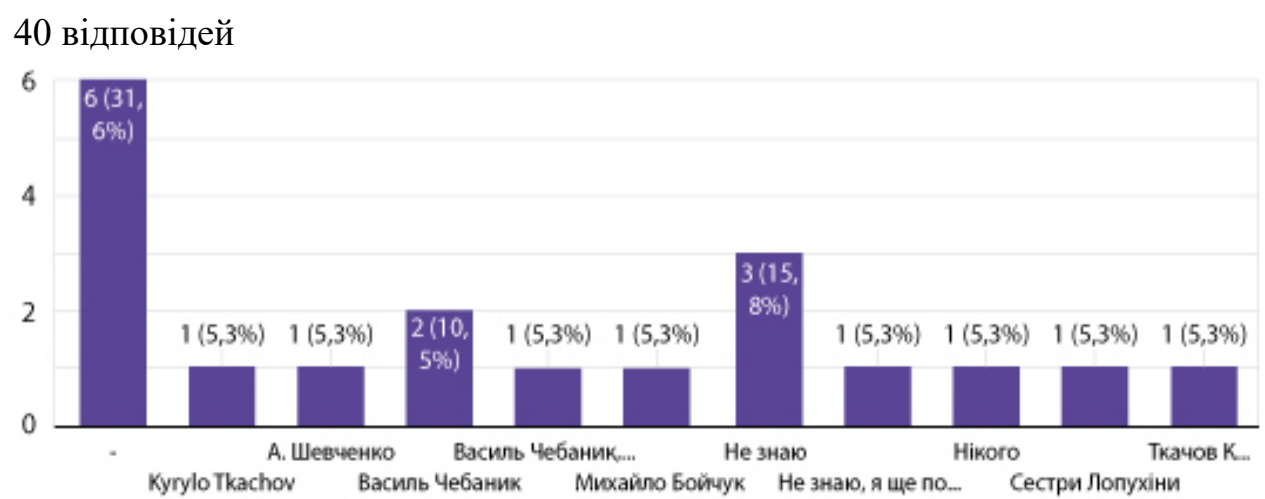

10) На Вашу думку, чи розвинута в Украйні каліграфічна писемність у графічному дизайні поліграфічної продукції на сьогоднішній день? 40 відпопідей

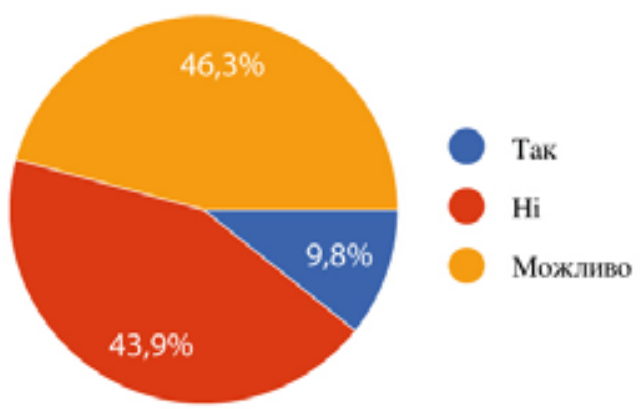

Продовження рис. 1. Діаграми, що відбивають результати емпіричних досліджень (анкетування)

надала перевагу каліграфічному письму (26,6 \%). Щодо візуального сприймання, то більшість респондентів надала перевагу дизайну, в якому використано каліграфічне українське письмо $(57,1 \%)$, менше осіб обрали гротескний шрифт (42,9 \%). Найвідомішими каліографами, за словами респондентів, є Кирило Ткачов, Василь Чебаник, Андрій Шевченко, Михайло Бойчук, сестри Лопухіни. На думку більшості респондентів, ймовірно, натепер каліграфічна писемність розвинута в дизайні поліграфічної продукції (46,3 \%), меншість чітко стверджує, що розвинута $(9,8 \%)$, менше половини опитуваних вважає, що не розвинута (43,9 \%) (табл. 1).

Висновки. Уперше введено в науковий обіг фактологічні й аналітичні матеріали про застосування каліграфічного українського письма в сучасному графічному дизайні. Авторський внесок співавторів: Р. Галишич - 30 \%, В. Крохмаль - $40 \%$, О. Мер'є - 30 \%. Визначено, що: 1) унікальність і креативність сучасних шрифтових каліграфічних композицій притягує увагу людини, викликає в неї інтерес, бажання та закликає до дій; 2) формотворення літер каліграфічного письма в дизайні етикеток згідно з характеристикою задає унікальність композиції, створює композиційний зв'язок; 3) сучасне каліграфічне оформлення обкладинок книжок акцентує на собі увагу внаслідок використання яскравих, контрастних форм; 4) у дизайні обгорток і пакування каліграфічний шрифт вишуканий, емоційний і настроєвий; 5) у текстовому оформленні дизайну плакату сучасний каліграфічний шрифт динамічний, таким чином, викликає в людини інтерес до змісту повідомлення. Згідно з результатами емпіричних досліджень встановлено, що естетика каліграфічного шрифту гарніша, ніж звичайні гротескові чи антиквенні шрифтові гарнітури; найчастіше каліграфічне письмо зустрічається в дизайні етикеток, плакатів, сертифікатів, запрошень; згідно з візуальним сприйманням, більшість респондентів обрали дизайн iз використанням каліграфічного письма. Встановлено, що зі стрімким розвитком тенденцій в українському графічному дизайні каліграфічна писемність характерно виражена й актуальна в дизайні поліграфічної продукції. Результати наукового дослідження можуть бути корисними для науки й практики - для подальших досліджень каліграфічного українського письма дизайнерами й каліографами, котрі цікавляться станом його розвитку й використовують у своїх роботах. 


\section{СПИСОК ВИКОРИСТАНИХ ДЖЕРЕЛ}

1. Дудник I. Українська літера. Латиниця витісняє кирилицю. Український шрифт просувають на голому ентузіазмі. Украӥнський Тиждень. 2009. № 26 (87). URL: http:/tyzhden.ua/Publication/3657 (дата звернення 20.04.2020).

2. Загаєцька О. Подвижник української книжкової графіки : про художника-графіка В. Я. Чебаника. Вітчизна. 2006. № 3-4. C. 172-176.

3. Задніпряний Г. Каліграфія - прекрасна гілка на дереві шрифтів. Арт-простір. 2018. № 3. С. 13-18.

4. Ісмайлова М. Візуально-образна мова типографіки у дизайні поліграфічних видань періоду раннього модернізму : автореф. дис. ... канд. мистецтвознавства : 17.00.07. Харків, 2019. 20 с.

5. Ісмайлова М. Типографіка як інструмент рішення функціональних та естетичних аспектів у дизайні поліграфічної рекламної продукції раннього модернізму (1910-1935). Вісник ХДАДМ. 2015. № 6. С. 61-70.

6. Ісмайлова М. Шрифт як основний засіб формоутворення візуально-образної мови типографіки в дизайні поліграфічної рекламної продукції періоду раннього модернізму. Вісник ХДАДМ. 2016. № 5. С. 24-32.

7. Калашнікова О. Зображальний аспект візуальної мови графічного дизайну (на матеріалі плаката) : автореф. дис. ... канд. мистецтвознавства : 17.00.07. Харків, 2011. 20 с.

8. Капр А. Эстетика искусства шрифта. Москва : Книга, 1979. 124 с.

9. КнабеГ. Энциклопедия дизайнера печатной продукции. Москва; Санкт-Петербург; Киев : Диалектика, 2006. $726 \mathrm{c}$.

10. Лаврентьева Е. Текст и контекст в графическом дизайне. Москва, 2008. 232 с.

11. Макарова А. Засоби побудови образу в графічному дизайні: система структурних взаємозв'язків : автореф. дис. ... канд. мистецтвознавства : 17.00.07. Харків, 2014. 20 с.

12. Мітченко В. Естетика українського рукописного шрифту. Київ : Грамота, 2007. 208 с.

13. Мітченко В. Каліграфія. Взаємовпливи шрифтів: теорія і практика; кирилиця і латиниця; історія і сучасність. Київ : Laurus, 2018. 288 c.

14. Мітченко В. Мистецтво скоропису в просторі українського бароко. Украӥнський світ. 1992. № 1. С. 24-25.

15. Полтавська Ю. Серцем відданий книзі: про художника-графіка В. Чебаника . Артанія. 2011. № 1. С. 16-24.

16. Проєкт «Графіка української мови». Комітет з наиіональної премії України імені Тараса Шевченка : вебсайт. URL: http://knpu.gov.ua/content/проект-«графіка-української-мови» (дата звернення: 08.05.2020).

17. Проненко Л. Каллиграфия для всех. Москва : Книга, 1990. 248 с.

18. Різник М. Письмо і шрифт. Київ : Вища школа, 1978. 132 с.

19. Рудер Э. Типографика. Москва : Книга, 1982. 286 с.

20. Сучасний український шрифтовий дизайн. Кирилівські читання : вебсайт. URL: http://cyreading.blogspot. com/2012/11/blog-post_29.html (дата звернення 12.05.2020).

21. Той, що «грає буквами»: В. Чебаник, нар. 05.08 .1933 р. в с. Клішківці Хотин. р-ну]. Українська культура. 2007. № 11. C. 21.

22. Тоотс Виллу. Современный шрифт. Москва : Книга, 1966. 272 с.

23. Умпелева О. Основы каллиграфии и леттеринга. Прописи. Москва, 2019. 112 с.

24. Чебаник В. Рідній мові - зримий образ: проєкт видатного графіка. Украӥнська культура. 2007. № 1. С. 19-21.

25. Чекаль А. Красота каллиграфии. Международная выставка каллиграфии : веб-сайт. URL: http://calligraphyexpo.com/participants/Alexey_Chekal/krasota-kalligrafii (дата звернення: 15.04.2020).

\section{REFERENCES}

1. Dudnyk I. Ukrainska litera. Latynytsia vytisniaie kyrylytsiu. Ukrainskyi shryft prosuvaiut na holomu entuziazmi [Ukrainian letter. Latin displaces Cyrillic. The Ukrainian font is promoted on naked enthusiasm]. Ukrainian Week, 2009, Nr 26 (87). URL: http://tyzhden.ua/Publication/3657 (Last accessed: 20.04.2020) [in Ukrainian].

2. Zahaietska O. Podvyzhnyk ukrainskoi knyzhkovoi hrafiky: [pro khudozhnyka-hrafika V. Ya. Chebanyka] [Ascetic of the Ukrainian book graphics: [about graphic artist V. Y. Chebanik]]. Fatherly, 2006, Nr 3-4, pp. 172-176 [in Ukrainian].

3. Zadniprianyi H. Kalihrafiia - prekrasna hilka na derevi shryftiv [Calligraphy - a beautiful branch on the font tree]. Art space, 2018, Nr 3, pp. 13-18 [in Ukrainian].

4. Ismailova M. S. Vizualno-obrazna mova typohrafiky u dyzaini polihrafichnykh vydan periodu rannoho modernizmu : avtoref. dys. na zdobuttia nauk. stupenia kand. mystetstvoznavstva : 17.00 .07 [Visual-shaped language of typography in the design of printing editions of the period of early modernism: abstract of the dissertation for the science degree of Ph.D in the Art History: 17.00.07]. Kharkiv, 2019. 20 p. [in Ukrainian].

5. Ismailova M. S. Typohrafika yak instrument rishennia funktsionalnykh ta estetychnykh aspektiv u dyzaini polihrafichnoi reklamnoi produktsii rannoho modernizmu (1910-1935) [Typography as a tool for the solution of functional and aesthetic aspects in the design of printing advertising products of early modernism (1910-1935)]. Bulletin KDADM, 2015, Nr 6, pp. 61-70 [in Ukrainian].

6. Ismailova M. S. Shryft yak osnovnyi zasib formoutvorennia vizualno-obraznoi movy typohrafiky v dyzaini polihrafichnoi reklamnoi produktsii periodu rannoho modernizmu [Font as the main means of forming visual and figurative language of typography in the design of printing advertising products of the period of early modernism]. Bulletin KDADM, 2016, $\mathrm{Nr} 5$, pp. 24-32 [in Ukrainian].

7. Kalashnikova O. A. Zobrazhalnyi aspekt vizualnoi movy hrafichnoho dyzainu (na materiali plakata): avtoref. dys. na zdobuttia nauk. stupenia kand. mystetstvoznavstva : 17.00.07 [Depictive aspect of the visual language of graphic design (on the material of the poster): abstract of the dissertation for the science degree of Ph.D in the Art History: 17.00.07]. Kharkiv, 2011. 20 p. [in Ukrainian]. 
8. Kapr A. Estetyka yskusstva shryfta [Aesthetics of the font bite]. Moscow : The book, 1979. 124 p. [in Russian].

9. Knabe H. A. Entsyklopedyia dyzainera pechatnoi produktsyy [Encyclopedia of the designer printed products]. Moscow; St. Petersburg; Kiev : Dialectics, 2006. 726 p. [in Russian].

10. Lavrenteva E. Tekst y kontekst $\mathrm{v}$ hrafycheskom dyzaine [Text and context in graphic design]. Moscow, $2008.232 \mathrm{p}$. [in Russian].

11. Makarova A. L. Zasoby pobudovy obrazu v hrafichnomu dyzaini: systema strukturnykh vzaiemozviazkiv : avtoref. dys. na zdobuttia nauk. stupenia kand. mystetstvoznavstva : 17.00.07 [Means of building an image in graphic design: system of structural relationships : abstract of the dissertation for the science degree of Ph.D in the Art History: 17.00.07]. Kharkiv, 2014. 20 p. [in Ukrainian].

12. Mitchenko V. Estetyka ukrainskoho rukopysnoho shryftu [Aesthetics of Ukrainian handwritten font]. Kyiv : Charter, 2007. 208 p. [in Ukrainian].

13. Mitchenko V. Kalihrafiia. Vzaiemovplyvy shryftiv: teoriia i praktyka; kyrylytsia i latynytsia; istoriia i suchasnist [Calligraphy. Mutual influential fonts: theory and practice; Cyrillic and Latin; history and modernity]. Kyiv : Laurus, 2018. 288 p. [in Ukrainian].

14. Mitchenko V. Mystetstvo skoropysu v prostori ukrainskoho baroko [The art of short-writing in the space of the Ukrainian Baroque]. Ukrainian world, 1992, Nr 1, pp. 24-25 [in Ukrainian].

15. Poltavska Yu. Sertsem viddanyi knyzi: [pro khudozhnyka-hrafika V. Chebanyka] [Heart is devoted to the book: [about the graphic artist V. Chebanik]]. Artaniia, 2011, Nr 1, pp. 16-24 [in Ukrainian].

16. Proekt "Hrafika ukrainskoi movy" [Project «Graphics of the Ukrainian Language»]. Committee on Taras Shevchenko National Prize of Ukraine : website. URL: http://knpu.gov.ua/content/проект-«графіка-української-мови» (Last accessed: 08.05.2020) [in Ukrainian].

17. Pronenko L. Y. Kallyhrafyia dlia vsekh [Calligraphy for all]. Moscow : Book, 1990. 248 p. [in Russian].

18. Riznyk M. Pysmo i shrift [Writing and font]. Kyiv : Higher School, 1978. 132 p. [in Ukrainian].

19. Ruder E. Typohrafyka [Typography]. Moscow : Book, 1982. 286 p. [in Russian].

20. Suchasnyi ukrainskyi shryftovyi dyzain [Modern Ukrainian font design]. Kyryliv readings : website. URL: http://cyreading.blogspot.com/2012/11/blog-post_29.html (Last accessed: 12.05.2020) [in Ukrainian].

21. Toi, shcho "hraie bukvamy": [V. Chebanyk, nar. 05.08.1933 r. v s. Klishkivtsi Khotyn. r-nu] [The one that "plays letters": [V. Chebanik, born 05.08.1933 in the village of Klishkivtsi Khotyn district]]. Ukrainian culture, 2007, Nr 11, p. 21 [in Ukrainian].

22. Toots Vyllu. Sovremennyi shryft [Modern font]. Moscow : Book, 1966. 272 p. [in Russian].

23. Umpeleva O. Yu. Osnovy kallyhrafyy y letterynha. Propysy [Callygraphy and lettering basics. Prescription]. Moscow, 2019. 112 p. [in Russian].

24. Chebanyk V. Ridnii movi - zrymyi obraz: [proekt vydatnoho hrafika] [In his native language - a downloadable image: [project of outstanding graphics]]. Ukrainian culture, 2007, Nr 1, pp. 19-21 [in Ukrainian].

25. Chekal A. Krasota kallyhrafyy [The beauty of calligraphy]. International Calligraphy Exhibition : website. URL: http://calligraphy-expo.com/participants/Alexey_Chekal/krasota-kalligrafii (Last accessed: 15.04.2020) [in Russian]. 